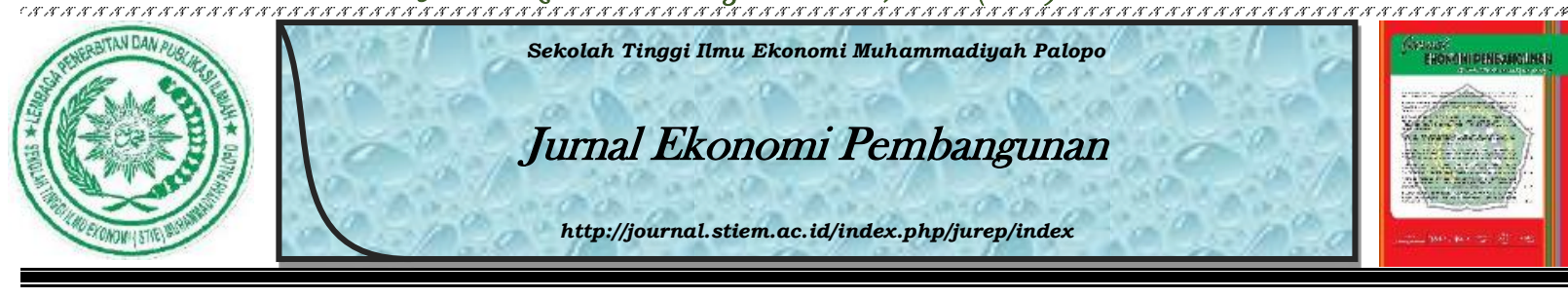

\title{
Sistem Pengendalian Internal terhadap Risiko Kredit Macet Kendaraan Bermotor pada PT Adira Finance Cabang Palopo
}

Saharuddin

$\underline{\text { Sekolah Tinggi Ilmu Ekonomi Muhammadiyah Palopo }}$

\author{
INFO NASKAH

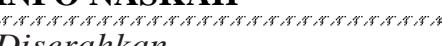 \\ Diserahkan \\ 17 Desember 2017 \\ Diterima \\ 18 Desember 2017 \\ Diterima dalam revisi \\ 18 Desember 2017 \\ Diterima dan disetujui \\ 19 Desember 2017

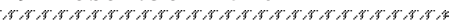

\section{Kata Kunci:}

Sistem pengendalian internal Risiko kredit macet

Pembiayaan

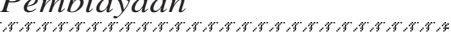

\begin{abstract}
ABSTRAK
Bisnis pembiayaan kendaraan bermotor merupakan salah satu bisnis yang memiliki tingkat risiko yang sangat besar. Usaha untuk mengurangi risiko yang akan timbul dalam proses pemberian kredit, perusahaan memperketat dan mengevaluasi prosedur yang digunakan untuk pengkreditan dengan cara menerapkan system pengendalian internal. Penelitian ini bertujuan mengidentifikasi dan mengevaluasi sistem pengendalian internal terhadap risiko kredit macet kendaraan bermotor pada PT Adira Finance Cabang dan mengidentifikasi dampak penerapan pengendalian internal terhadap risiko kredit macet kendaraan bermotor pada PT Adira Finance Cabang Palopo. Penelitian ini menggunakan pendekatan kuantitatif dengan alat analisis regresi linear sederhana. Hasil penelitian ini menunjukkan bahwa terdapat hubungan yang cukup signifikan antara sistem pengendalian internal dengan risiko kredit macet kendaraan bermotor pada PT Adira Finance Cabang Palopo dimana nilai korelasinya $61,6 \%$ dan determinasinya $37,9 \%$.
\end{abstract}

\section{Pendahuluan}

Perusahaan pembiayaan di Indonesia menjadi sesuatu yang mudah kita jumpai. Biasanya model perusahaan ini telah bergabung kepada suatu merek produk tertentu. Hal tersebut dilakukan untuk memudahkan transaksi jual-beli yang dilakukan secara kredit terhadap suatu produk. Pengelolaan pembiayaan tidak dapat dilakukan secara sembarangan, tetapi harus dengan pertimbangan dan pengawasan yang memadai agar tidak terjadi masalah yang dapat merugikan dan bahkan dapat berakibat kebangkrutan.

Bisnis pembiayaan sepeda motor dan mobil merupakan salah satu bisnis yang memiliki tingkat risiko sangat besar. Risiko itu antara lain adalah prepayment yaitu nasabah melunasi utang mereka lebih awal dari perjanjian semula dan default yaitu nasabah tidak mampu melunasi hutang atau kredit kendaraan sepeda motor dan mobil sesuai jatuh tempo pembayaran. 
Selain prepayment dan default, perusahaan pembiayaan mengalami risiko pengurangan nilai dari kendaraan yang disita dari para nasabah yang tidak mampu melunasi kreditnya.

PT Adira Finance dalam proses menanggulangi risiko prepayment, pada umumnya dapat menggunakan strategi menghindari risiko tersebut dengan membuat suatu kebijakan mengenai prosedur dan tata cara pembayaran kredit kendaraan bermotor dimana salah satu prosedur tersebut mewajibkan nasabah membayar sesuai dengan jangka waktu yang telah ditetapkan, tidak boleh kurang dari waktu tersebut atau lebih dari waktu tersebut.

Berdasarkan uraian di atas, usaha untuk mengurangi risiko yang akan timbul dalam proses pemberian kredit, perusahaan bisa memperketat dan mengevaluasi prosedur yang digunakan untuk pengkreditan, dengan cara melakukan pengendalian internal. Pengendalian sistem internal harus dilakukan sebagai dasar agar kegiatan operasional perusahaan dan manajemen juga berjalan dengan baik. Penelitian ini bertujuan mengidentifikasi dan mengevaluasi sistem pengendalian internal terhadap risiko kredit macet kendaraan bermotor pada PT Adira Finance Cabang Palopo. Selain itu, penelitian ini juga bertujuan mengidentifikasi dampak penerapan pengendalian internal terhadap risiko kredit macet kendaraan bermotor pada PT Adira Finance Cabang Palopo.

\section{Metode Penelitian}

Penelitian ini dilakukan pada PT Adira Finance Cabang Palopo yang terletak di Kota Palopo. Adapun metode analisis yang digunakan adalah menggunakan metode analisis regresi sederhana dengan formulasi matematis sebagai berikut

$Y=a+b X+e \quad$ (Suliyanto, 2011)

dimana $Y$ adalah system pengendalian internal; $X$ adalah risiko kredit macet; $a$ adalah konstanta; dan $b$ adalah koefisien regresi; dan $e$ adalah error term.

\section{Hasil dan Pembahasan}

\subsection{Hasil}

PT Adira Finance merupakan perusahaan yang bergerak di bidang pembiayan unuk berbagai merek otomotif di Indonesia yang sudah ada sejak tahun 1990. Sejalan dengan perkembangan zaman, PT Adira Finance lebih berkonsentrasi kepada pembiayaan dengan tingkat pengembalian yang tinggi baik itu dalam sektor pembiayaan sepeda motor maupun mobil, baru atau bekas, berbagai merek tanpa harus terkait dengan salah satu merk tertentu. 
Selain itu, PT Adira Finance juga melakukan usaha peminjaman dana bagi konsumen yang membutuhkan dana dengan jaminan BPKB sepeda motor tersebut. Karyawan PT Adira Finance lebih dari 28 ribu dan lebih dari 245 jaringan usaha yang tersebar di Indonesia dan salah satunya ada di kota Palopo.

Selama PT Adira Finance berdiri di Kota Palopo, timbul berbagai pokok persoalan diantaranya:

a. Unit dan nasabah raib;

b. Debitur atau penjamin memberikan suatu data dokumen yang tidak valid atau tidak sesuai dengan fakta;

c. Jaminan yang dipindahtangankan tanpa adanya laporan ke perusahaan;

d. Unit di gadai; dan

e. Debitur atau nasabah lari atau pergi ke luar kota.

Beardasarkan masalah yang tersebut, PT Adira Finance menempuh/menyelesaikan sengketa melaui jalur hukum khususnya menyelesaikan kredit macet tersebur. PT Adira Finance menempuh jalur ini dengan mengajukan gugatan secara perdata dan/atau pelaporan tindak pidana. Pengajuan gugatan secara perdata terhadap debitur dengan wanprestasi pihak perusahaan pembiayaan dapat mengajukan gugatan perdata tersebut ke pengadilan negeri setempat dengan tuntutan ganti rugi.

Ketentuan mengenai wanprestasi telah dimuat secara tegas dalam perjanjian pembiayaan konsumen yang termuat dalam syarat-syarat perjanjian pembiayaan konsumen dengan penyerahan hak milik secara fidusia antara PT Adira Finance dengan debitur. Isi perjanjian tersebut mengatur tentang wanprestasi yang menyatakan bahwa:

"Penerimaan fasilitas atau penerima jaminan setuju dan mengikat diri kepada pemberi fasilitas dan/atau kuasanya mengenai terjadinya atau keadaan wanprestasi yang dengan lewatnya waktu telah cukup membuktikan terjadinya salah satu atau keadaan".

PT Adira Finance Cabang Kota Palopo lebih menggunakan jasa eksternal collection yang akibatnya tidak semua kredit macet yang dilakukan oleh debitur dapat dilakukan penarikan sehingga tidak ada efek jera kepada debitur yang melakukan wanprestasi. Sistem Pengendalian Internal merupakan kumpulan dari pengendalian intern yang terintegrasi, berhubungan dan saling mendukung satu dengan yang lainnya. Pengendalian internal dirancang untuk memberi suatu keyakinan akan tercapainya tujuan perusahaan yang secara umum dibagi kedalam tiga 
kategori sebagai berikut:

a. Keefektifan dan efisiensi operasional perusahaan;

b. Pelaporan Keuangan yang handal; dan

c. Kepatuhan terhadap prosedur dan peraturan yang diberlakukan.

\section{Pengujian Hipotesis}

Hipotesis penelitian dalam penelitian ini diuji dengan analisis regresi sederhana. Hasil pengujian hipotesis dalam penelitian ini terlihat dalam tabel berikut ini:

Tabel 1. Hasil Pengujian Hipotesis

\begin{tabular}{|l|c|c|c|}
\hline \multirow{2}{*}{ Variabel } & \multicolumn{2}{|c|}{$\begin{array}{c}\text { Model } \\
\text { (Risiko Kredit Macet) }\end{array}$} & \multirow{2}{*}{ Kesimpulan } \\
\cline { 2 - 3 } & Koefisien & Signifikansi & \\
\hline \multicolumn{1}{|c|}{ Konstanta } & 0,784 & & \\
\hline Sistem Pengendalian Internal & 0,647 & 0,000 & Terdukung \\
\hline$R=0.616$ & & \\
$R^{2}=0.379$ & & \\
Adj $R=0.372$ & & \\
$T$ - Stat $=7.532$ & & \\
\hline
\end{tabular}

Berdasarkan tabel di atas, dapat dijelaskan Nilai R (korelasi) adalah nilai yang menjelaskan hubungan atau keterkaitan antara sistem pengendalian internal dengan risiko kredit macet kendaraan bermotor pada PT Adira Finance Cabang Palopo dimana nilai R $(0,616)$ atau 61,6\% adalah menjelaskan bahwa korelasi atau hubungan antara sistem pengendalian internal dengan risiko kredit macet kendaraan bermotor pada PT Adira Finance Cabang Palopo cukup signifikan. Sementara nilai determinasinya yakni R Square $(0,379)$ atau $37,9 \%$ artinya ketergantungan antara sistem pengendalian internal dengan risiko kredit macet kendaraan bermotor pada PT Adira Finance Cabang Palopo adalah 37,9\% sedangkan 62,1\% dipengaruhi oleh faktor lain.

\subsection{Pembahasan}

Berdasarkan hipotesis yang diduga penerapan sistem pengendalian internal berpengaruh signifikan terhadap risiko kredit macet kendaraan bermotor pada PT Adira Finance Cabang Palopo. Sistem pengendalian internal dalam penelitian ini berpengaruh signifikan terhadap risiko kredit macet (terdukung). Berdasarkan tabel di atas, maka dapat dijelaskan persamaan regresinya sebagai berikut:

$\mathrm{Y}=0.784+0.647(\mathrm{X})$ 
Ini menunjukkan besarnya pengaruh sistem pengendalian internal (arah positif), artinya apabila sistem pengendalian internal meningkat skornya satu satuan, maka diprediksikan skor risiko kredit macet kendaraan bermotor pada PT Adira Finance Cabang Palopo hanya sebesar 0,647 poin.

\section{Simpulan dan Saran}

Berdasarkan hasil pembahasan dari penelitian yang diuraikan oleh penulis, maka kesimpulan dari hasil penelitian ini adalah terdapat pengaruh yang cukup signifikan antara sistem pengendalian internal terhadap risiko kredit macet kendaraan bermotor pada PT Adira Finance Cabang Palopo dan terdapat hubungan yang kuat antara sistem pengendalian internal dengan risiko kredit macet kendaraan bermotor pada PT Adira Finance Cabang Palopo dimana nilai korelasinya $\mathrm{R}=0,616$ atau $61,6 \%$ dan determinasinya $\mathrm{r}^{2}=0,379$ atau $37,9 \%$.

\section{Daftar Pustaka}

. 2008. Manajemen Perbankan. Edisi Revisi. Jakarta: Raja Graffindo Persada. . 2009. Analisis Laporan Keuangan. Jakarta: Raja Graffindo Persada. . 2010. Bank dan Lembaga Keuangan Lainnya. Jakarta: Raja Graffindo Persada. . 2010. Sistem Akuntansi. Jakarta: Salemba Empat.

Amanina, R. 2011. Evaluasi Terhadap Sistem Pengendalian Intern pada Proses Pemberian Kredit Mikro.

http://eprints.undip.ac.id/26647/1/SKRIPSI/Ruzanna_Amanina_C2C607134_\%28r\%29.

Diana, A dan L. Setiawati. 2011. Sistem Informasi Akuntansi: Perencanaan, Proses, dan Penerapan. Yogyakarta: Andi.

http://kopkarti.wordpress.com/2013/06/10/cara-penyelesaian-kredit-macet. Diakses tanggal 06 April 2014.

Ismail. 2010. Manajemen perbankan: Dari Teori Menuju Aplikasi. Jakarta: Kencana Prenadamedia Group.

Karim, A. 2006. Bank Islam Analisis Fiqih dan Keuangan. Jakarta: PT Grafindo Persada.

Kasmir. 2008. Dasar Dasar Perbankan. Jakarta: Raja Graffindo Persada.

Kuncoro, D.A. 2011. Evaluasi Sistem Pengendalian Intern Pemberian Kredit Pada PD BKK Mojosongo Boyolali. http://eprints.uns.ac.id /2293/1/187341812201106091.pdf. 
Mulyadi. 2008. Auditing. Jakarta: Salemba Empat.

Ratri, T.M. 2014. Penanganan Kredit Macet dalam Penyaluran Kredit Usaha Rakyat (KUR) di Industri Rumah Tangga oleh Bank JATIM. Jurnal Ilmu \& Riset Akuntansi, 3 (11).

Republik Indonesia. Undang-Undang RI Nomor 10 tahun 1998 Tentang Perubahan atas Undang-Undang Nomor 7 tahun 1992 tentang Perbankan.

Rivai, V., A.P. Veithzal dan F.N. Idroes. 2007. Bank and Finance Institution Management: Conventional and Sharia System. Jakarta: Raja Graffindo Persada.

Syafi'i Antonio, M. 2001. Bank Syariah dari Teori ke Praktek. Jakarta: Gema Insani Press.

Wijaya, N.C. 2005. Evaluasi Sistem Pengendalian Intern Pemberian Kredit Pada KPRI Bina Sejahtera RC Prof. Soeharso Surakarta. http://eprints.uns.ac.id/10666/1/67612206200905041.pdf. 